\title{
Conventional Dairy Farmers Converting to Organic Dairy Production in Turkey
}

\author{
Tayfun Cukur* \\ Department of Marketing and Advertising, Mugla Sitki Kocman University Milas Vocational School, \\ 48200, Milas, Mugla, Turkey
}

Received: 4 March 2015

Accepted: 10 April 2015

\begin{abstract}
Organic agriculture is a form of agricultural production in which chemical input is not used and where each step from production to consumption is controlled and certified. Organic agriculture is focused on realizing agricultural activities without polluting soil, air, and water sources. In addition, organic agriculture is an environment-friendly production form that protects plants, animals, and human health. Therefore, adopting and applying organic agriculture methods is increasingly being considered by farmers. There are three primary aims of this study: to determine whether or not dairy farmers are aware of organic agriculture, to determine farmers' tendency toward organic production, and to determine the effective factors on farmers' tendencies to produce organic milk. In the study, probit analysis was used with the purpose of determining the factors on farmers' tendencies to produce organic milk in the future. According to the conducted probit analysis results, a positive relationship exists between considering enlarging the farm, applying innovations, being informed about organic agriculture, and farmers' tendencies to produce organic milk in the future. On the other hand, a negative relationship was found between the distance of the farm to the Milas district center, educational level of the farmers, and farmers' tendencies to produce organic milk in the future. It was determined that an important part of the participating farmers had information about organic agriculture. However, the main reason for farmers to tend not to produce organic milk in the future is not having sufficient information about organic agriculture. Therefore, courses and seminars should be held to increase the knowledge level of farmers in the district about organic stockbreeding. In addition, education and extension activities aimed at organic milk production should be organized. Thus farmers with insufficient information about organic agriculture and those with no information about organic agriculture would be informed about this subject.
\end{abstract}

Keywords: organic agriculture, dairy farmers, conversion, probit, Milas, organic milk

\section{Introduction}

Organic agriculture is a production system that sustains the health of soils, ecosystems, and people. It relies on ecological processes, biodiversity, and cycles adapted to local conditions, rather than the use of inputs with adverse effects. Organic agriculture combines tradition, innovation and science to benefit the shared environment

*e-mail: tayfunc@mu.edu.tr and promote fair relationships and a good quality of life for all involved.

The four principles of organic agriculture are:

- Sustaining and enhancing the health of the soil, plants, animals, humans, and the planet as one and indivisible.

- It should be based on living ecological systems and cycles, and work with them, emulate them and help sustain them.

- Building on relationships that ensure fairness with regard to the common environment and life opportunities. 
- Managing in a precautionary and responsible manner to protect the health and well-being of current and future generations and the environment [1].

Organic agriculture in Turkey started in 1984 with the demand for dried grapes and figs by foreign buyers, and then continued with apricot and nut production. The product range increased to eight in a short time but did not increase until the early 1990's. In the following years - in line with the development of organic agriculture around the world - the socio-economic importance of the subject and accordingly the number of organic products increased in Turkey [2]. By 2012 organic agriculture was practiced on 54,635 Turkish farms, encompassing 702,909 hectares of land and 204 crops [3].

Organic livestock farming is production activity carried out under control and certificate with environmentally friendly production techniques for consumers who demand qualified, healthy, and risk-free products. One of the reasons for farmers to move toward organic livestock farming is to increase income due to high organic milk prices [4].

Due to principles of organic production (such as use of organic feed, suitable sheltering conditions, suitable animal species, and animal health) production costs are higher than conventional livestock farming. Therefore, the suitable price of organic products produced for business profitability is important in the sense of creating demand [5]. When the literature is analyzed, it is seen that there are few studies where organic and conventional milk production is compared in an economic sense, and comparisons are carried out rather in a technical sense.

Butler [6] found that production costs for California organic dairies were about $10 \%$ higher, while net farm income was about twice that of conventional dairies. Dalton et al. [7] stated that revenue on organic farms was $36 \%$ higher than on their non-organic counterparts. Organic dairying can be as or more profitable than grazing and conventional dairy systems [8]. According to Bennett and Franzel [9] organic and resource-conserving agriculture provides increases of yield, food security, and net income. McBride and Greene [10] indicated that organic dairies had production costs about $\$ 5$ to $\$ 7$ per cwt higher than conventional dairies and received an average milk price premium of $\$ 6.69$ per cwt. Parsons [11] stated that with higher milk prices but lower milk per cow, organic dairy farms were comparably profitable with conventional farms, and due to the contracts were more stable economically. Nemes [12] stated that organic agriculture was economically more profitable, and even though yields decrease in developed countries, higher premiums and lower production costs compensate for these losses.

Organic dairy cattle farming has not started yet in Milas, where the study is carried out. In a study carried out by Karabaş and Gürler [13] in Samsun, Turkey it was analyzed whether producers who carry out organic and conventional agriculture act differently. In the study it was concluded that producers who conduct conventional agriculture do not pass to organic agriculture due to loss of yield in organic agriculture, having no information about organic agriculture and making no production for the market. In a study carried out in Kelkit Gümüşhane, Turkey by Bayram et al. [14] it was determined that milk yield obtained on farms where organic agriculture is carried out is higher than farms where conventional agriculture is carried out. Kizılaslan and Olgun [15] stated that retail conventional milk sale price is $1.75 \mathrm{TL}$ and retail organic milk sale price is $4.05 \mathrm{TL}$. Income of farmers who produce organic cattle meat in Turkey is $35 \%$ higher than income of farmers who produce conventional cattle meat [16].

Although organic honey production has been carried out for long years as the first and only organic animal production in Turkey, organic meat, milk, and egg production started recently and has been increasing [17]. The number of farms engaged in organic stockbreeding $(1,587$ by 2012$)$ is lower than the number of farms that are engaged in organic crop production [3].

Farmers who conduct organic agriculture in crop and animal production are supported in Turkey. "Announcement for Organic Stockbreeding Support Payment" entered into force after being published in an official gazette dated 20.07.2013 (No. 28713). The announcement was prepared in order to determine procedures and principles for supporting animal breeders who conduct organic livestock breeding for development of organic livestock farming, which causes no harm to the environment and human health, protects natural resources, and enables welfare, security, and sustainability of animals. Organic stockbreeding supports about dairy farming as such: 150 $\mathrm{TL} /$ head for broodstock cow/buffalo, $50 \mathrm{TL} / \mathrm{head}$ for calves [18].

Milas district is located in southwestern Turkey. Milas is one of the districts in Muğla with high agricultural potential. Milas had 80,173 hectares of arable land, 7,541 hectares of pasture, 119,019 hectares of forest, and 24,883 hectares of barren land in 2013. Tobacco, cotton, sesame, wheat, barley, olives, and olive oil can be counted among the important agricultural products for the development of the district. It also has important potential with regards to cattle farming. Dairy farming is one of the most important sources of income for many families who make their living by farming. Milas district had 72,028 bovine animals by the year 2013 [19].

Organic olives are being produced in Milas district, but dairy farms in the district are not yet engaged in organic agriculture. The existence of organic agriculture in the district, even by the means of plant production, can be considered as an advantage with regards to "organic farming culture."

Knowledge about the factors that affect farmers' decision to convert to organic farming is a prerequisite for the formulation of policies for the support of a widespread transition from the current situation to wished-for safe organic agricultural practices [20]. Several studies show that organic farming is more profitable than conventional farming. However, in reality not many farmers convert to organic farming. Policy makers and farmers do not have clear insight into factors that hamper or stimulate the conversion to organic farming [21]. 
De Cock [22] stated that the more a farmer seeks information about organic farming, the higher his intention to convert. Kallas et al. [23] found that farmers who are not risk-averse were more prone to adopt organic farming. The findings obtained by Mzoughi [24] showed that farmers who give high importance to economic considerations (e.g., cutting production costs) were less likely to adopt organic farming. Constance and Choi [25] determined that for the pragmatic conventional producers, an increase in revenue would be a major facilitator of organic adoption. Singh et al. [26] determined that older farmers were reluctant to change and thus have a lower tendency to adopt organic farming. Khaledi et al. [27] found that while the education levels of organic farmers show no significant effect on the probability of adoption, younger organic farmers allocate significantly less of their cultivated area to organic practices. Nahuelhual et al. [28] determined that the probability of adoption was found to be positively correlated with farmer's education and age, awareness of environmental regulations, the type of milk buyer, and the use of complementary cleaner production management practices. Latruffe et al. [29] reported that farmers who switched to organic farming were more technically efficient (before conversion) than farmers who remained conventional, but they had experienced a slowdown in technical efficiency (also before conversion). Latruffe et al. [30] found that the availability of a supply of shared machinery cooperative or contract work services for organic production significantly raises the probability of conversion.

Asadollahpour et al. [31] found that factors affecting the conversion to organic farming fall under two main categories: facilitators and barriers. The facilitating factors include motivations and profits. Health and safety motivations, environmental motivations, knowledge motivations, ideological and philosophical motivations, and economic motivations were important factors mentioned by rice producers. A study conducted by Azam [32] found that government agencies can play a critical role in promoting organic farming by appointing experts to deal with the marketing aspects, crop diseases, certification issues, and promoting the concept of "community farming," which reduces overall cost of cultivation. Sharifi et al. [33] indicated that major barriers or obstacles to the adoption of organic farming were: productivity, attitude and knowledge, infrastructure, and economics. Results obtained by Padel [34] showed that the conversion decision of the individual farmer could not be explained on the basis of traditional personal characteristics of the adopters alone; other factors need to be considered, such as policy support and the development of the markets as well as the attitude toward organic farming in the agricultural community and institutional development. Sarker et al. [35] determined that perceptions of organic farming household access to extension services, number of family laborers, and household income were significantly associated with decisions to adopt organic farming. Isin et al. [36] found that education status, age, fig-growing experience of the producers, and fig production amount were important parametres in the adoption of organic dried fig agriculture.
As shown above there are many factors affecting farmers' adoption and application in organic farming. For this reason the main aim of the study is to determine the important influencing factors for adoption of organic dairy farming in Milas District.

\section{Materials and Methods}

\section{Data Collection}

The personal interview method was used in this study. The survey was conducted with 71 farmers. The first part of the survey included questions about age, educational level, marital status, and agricultural and stockbreeding experience. The following parts of the survey included various questions that helped gain an idea about the tendencies of farmers toward organic agriculture. The Likert scale was used to determine the significance level of the factors that might be effective for organic milk production of farmers in the future.

After the preparation of the survey form, it was pre-tested with three farmers and the survey took its final form. The farmers were visited for the survey, which was conducted in village coffeehouses and their farms. The 2,397 farmers registered at the Milas Dairy Farmers Union were the population of the study (because of the union's up-todate records). Within the scope of the study, interviews were conducted with the farmers determined through proportional sampling [37]. The study was based on a $90 \%$ confidence interval and $10 \%$ margin of error. The data belong to the period of July-August 2014. Thirteen neighborhoods (villages) in the district were included in the scope of the study.

$$
n=\frac{N p(1-p)}{(N-1) \sigma_{p x}^{2}+p(1-p)}
$$

...where:

$n$ - Sample size

$N-$ Population

$p$ - Proportion of farmers wanting to convert to organic farming $(0.50)$

$(1-p)$ - Proportion of farmers not wanting to convert to organic farming $(0.50)$

$\sigma_{p x}^{2}-$ Variance (for $\alpha=0.10 \sigma_{p}=0.06079$ )

With this calculation, the total number of farmers to be interviewed was determined to be 66. With the interview of five additional farmers for contingency, a total of 71 questionnaires were taken into consideration. As for the distribution of farmers to villages the principle of proportional representation was followed.

\section{Statistical Analysis}

We used probit analysis for the purpose of determining the factors on farmers' tendencies to produce organic milk in the future. Farmers who considered producing organic milk in the future were coded as 1 , and farmers who did not 
Table 1. Independent variables in the probit model.

\begin{tabular}{|c|c|c|c|c|c|}
\hline Acronym & Variable description & Type of measurement & Mean & Minimum & Maximum \\
\hline AGE & Age & 1 if dairy farmer's age is $<40 ; 0$ otherwise & 0.10 & 0 & 1 \\
\hline EDU & Education & $\begin{array}{l}0 \text { if dairy farmer has primary school degree or less; } 1 \text { if more } \\
\text { educated }\end{array}$ & 0.18 & 0 & 1 \\
\hline HOUS & Household size & 1 if household $<5$; 0 otherwise & 0.79 & 0 & 1 \\
\hline AGEX & Agricultural experience & 1 if agricultural experience $>20$ years; 0 otherwise & 0.76 & 0 & 1 \\
\hline ANEX & Dairy experience & 1 if dairy farming experience $>20$ years; 0 otherwise & 0.65 & 0 & 1 \\
\hline DIST & Distance from Milas & 1 if farm distance to Milas $<11 \mathrm{~km}$; 0 otherwise & 0.23 & 0 & 1 \\
\hline ANIM & Number of milked cows & 1 if cows milked $>4 ; 0$ otherwise & 0.35 & 0 & 1 \\
\hline MILK & Milk production & 1 if daily milk production $>99 ; 0$ otherwise & 0.23 & 0 & 1 \\
\hline MILA & Travel to Milas district & 1 if dairy farmers travel to Milas district frequently; 0 otherwise & 0.54 & 0 & 1 \\
\hline CROP & Crop production & 1 if farmers cultivate crop production; 0 otherwise & 0.93 & 0 & 1 \\
\hline NON & Non-agricultural income & 1 if farmers have non-agricultural income; 0 otherwise & 0.39 & 0 & 1 \\
\hline CRED & Using credit & 1 if farmers have used credit in last five years; 0 otherwise & 0.69 & 0 & 1 \\
\hline INCR & Expand the farm & 1 if farmers want to expand the farms; 0 otherwise & 0.38 & 0 & 1 \\
\hline BEEF & Beef cattle farming & 1 if farmers do beef cattle farming; 0 otherwise & 0.61 & 0 & 1 \\
\hline REC & Farm records & 1 if dairy farmers keep farm records regularly; 0 otherwise & 0.28 & 0 & 1 \\
\hline CONT & Continue farming & 1 if farmers want to continue agriculture; 0 otherwise & 0.70 & 0 & 1 \\
\hline SILA & Silage cultivation & 1 if farmers cultivate silage crops; 0 otherwise & 0.79 & 0 & 1 \\
\hline FORA & Forage crop cultivation & 1 if farmers cultivate forage crops; 0 otherwise & 0.82 & 0 & 1 \\
\hline COOP & Cooperative membership & 1 if farmer is a cooperative member; 0 otherwise & 0.45 & 0 & 1 \\
\hline INNO & Apply innovations & 1 if farmer applies innovations; 0 otherwise & 0.89 & 0 & 1 \\
\hline ORGA & Organic agriculture & $\begin{array}{l}1 \text { if farmer has information about organic agriculture; } \\
0 \text { otherwise }\end{array}$ & 0.59 & 0 & 1 \\
\hline SEMI & Participating seminar & $\begin{array}{l}1 \text { if farmer participates in seminar/meeting about organic } \\
\text { agriculture; } 0 \text { otherwise }\end{array}$ & 0.38 & 0 & 1 \\
\hline
\end{tabular}

consider producing organic milk in the future were coded as 0 in the probit model. The independent variables used in probit model are shown in Table 1 .

The estimating model that emerges from the normal cumulative distribution function (CDF) is popularly known as the probit model, although sometimes it is also known as the normit model [38].

The probit model is generally defined as $\operatorname{Pr}(y=1 \mid x)=$ $\Phi(x b)$, where $\Phi$ is the standard cumulative normal probability distribution and $\mathrm{xb}$ is called the probit score or index. The probit method fits discrete binary data by a maximum likelihood method to estimate the parameters. The maximum likelihood estimator is an estimator for unknown vectors of parameters. The likelihood function is defined by $L(\bar{\theta} ; y)=f(y ; \bar{\theta})$. Maximizing the likelihood function with respect to $\bar{\theta}$ means identifying a specific value, which is denoted by $\bar{\theta}$. This estimate maximizes the probability that a sample value has actually been observed. The log-likelihood function for probit is:

$$
\ln L=\sum w_{i} \ln \Phi\left(x_{j} b\right)+\sum w_{i} \ln \left(1-\Phi\left(x_{j} b\right)\right)
$$

\section{Results}

\section{General Characteristics of the Farms}

The distance of the farms from Milas city center averaged $16.53 \mathrm{~km}$. While $60.6 \%$ of the farms performed both beef cattle and dairy farming, $39.4 \%$ performed only dairy farming. The farmers were found to have small-scale farms. It was determined that the average number of cows milked on the farms was 4.95 and that daily milk production averaged 80.11 1. It was determined that $85 \%$ of the farmers used milking machines. The percentage of the farmers that produced maize for silage was $78.9 \%$. $81.7 \%$ of the farmers produced forage crops. $4.2 \%$ of the farmers have their cows insured. All farmers who participated in the study stated that all of their cows had ear tags. $38 \%$ of the farmers stated that they had automatic waterers on their farms. $98.6 \%$ of the farmers stated that they gave due importance to milking and barn hygiene. $47.9 \%$ of the farmers stated that vitamins were given to their cows. $42.3 \%$ of the farmers perform preventive medical practices on their cows. 
Table 2. People and institutions where farmers first got information about organic agriculture.

\begin{tabular}{|l|c|c|}
\hline & $\begin{array}{c}\text { Number of } \\
\text { farmers* }\end{array}$ & $\%$ \\
\hline Friends and neighbors & 4 & 7.8 \\
\hline $\begin{array}{l}\text { Milas Directorate of District Food } \\
\text { Agriculture and Livestock }\end{array}$ & 13 & 25.5 \\
\hline Sellers of fertilizers and pesticides & 2 & 3.9 \\
\hline Radio, television, magazines & 16 & 31.4 \\
\hline Exporting companies & 2 & 3.9 \\
\hline $\begin{array}{l}\text { Taris (Union of Agricultural } \\
\text { Producers and Sales Cooperatives) }\end{array}$ & 2 & 3.9 \\
\hline University/research institutes & 2 & 3.9 \\
\hline Internet & 1 & 2.0 \\
\hline Meeting, conference, seminar & 3 & 5.9 \\
\hline Veterinarian & 1 & 2.0 \\
\hline Agricultural fair & 4 & 7.8 \\
\hline Chamber of agriculture & 1 & 2.0 \\
\hline Total & 51 & 100.0 \\
\hline
\end{tabular}

*More than one answer was received

While $7 \%$ of the farmers who participated in the present study are solely engaged in dairy cattle farming, 93\% also are engaged in crop production. $39.4 \%$ of the farmers have income that is not related to agriculture. Farmers milk the cows twice a day - once in the morning and once in the evening. The milk obtained in the farms is sold to the Milas Dairy Farmers Union. Farmers who carry out crop production have an average of 46.2 decares of arable farm land.

\section{General Characteristics of the Farmers}

The interviewed farmers were middle aged, between 26 and 76 with an average of 53.6. Most farmers were primary school graduates. The years the farmers received education varied from 0 to 15 years with an average of 5.8 years. The average number of members in farmers' families was 3.6. In the present study, while the average farming experience of the farmers was determined to be 30.9 years, their average experience in dairy cattle farming was determined to be 28.4 years. While $95.8 \%$ of the farmers were married, $4.2 \%$ of them were single. In the study, it was determined that $45.1 \%$ of the farmers are members of cooperatives. In the study, it was determined that $69 \%$ of the farmers used bank credit. $28.2 \%$ of the farmers stated that they kept farm records regularly.

\section{Farmers' Views of Organic Farming Practices}

In recent years, due to the problems caused by conventional stockbreeding, consciousness of environmental protection has increased and animal welfare has become more important with the interest shown in animal rights. As a result, organic animal production is suggested as a solution to these problems. Organic (ecological, biological) animal production is a system that takes account of the health criteria in product quality along with the product amount. For this reason, the aim is that various synthetic chemical residues whose harmful effects are seen in the long term are either not found in organic products or are found at harmless levels in the microorganisms that cause diseases that are harmful to human health. Environmental protection and animal welfare also are taken into account [40].

It was determined that $59.2 \%$ of the participating farmers were informed about organic agriculture. It was determined that $38 \%$ of the farmers had attended a meeting/seminar about organic agriculture. Farmers were asked where they first heard about organic agriculture. Table 2 is based on these answers. $31.4 \%$ of the farmers stated that they heard the notion of organic agriculture from the media (radio, television, magazines) and $25.5 \%$ of them stated that they heard about it from the Milas Directorate of District Food Agriculture and Livestock.

$54.9 \%$ of the interviewed farmers do not have a tendency to convert to organic milk producing. $35.4 \%$ of the aforementioned farmers stated that they did not have sufficient information about organic agriculture. $16.7 \%$ of the farmers stated that since their labor force and time were insufficient, they did not want to produce organic milk. And $12.5 \%$ of the farmers think that organic milk production requires more effort. Again, $12.5 \%$ of the farmers did not consider producing organic milk since there are no other farmers around them producing organic milk (Table 3).

When asked if they would consider producing organic milk in the future, $45.1 \%$ of the farmers answered yes. When the factors that might affect farmers' (32 farmers)

Table 3. Reasons that farmers do not have tendency to produce organic milk in the future.

\begin{tabular}{|l|c|c|}
\hline & $\begin{array}{c}\text { Number of } \\
\text { farmers* }\end{array}$ & $\%$ \\
\hline Decrease of efficiency & 3 & 6.3 \\
\hline Requires more effort & 6 & 12.5 \\
\hline $\begin{array}{l}\text { I do not have sufficient informa- } \\
\text { tion about organic agriculture }\end{array}$ & 17 & 35.4 \\
\hline There is no market guarantee & 2 & 4.2 \\
\hline No one around me does it & 6 & 12.5 \\
\hline $\begin{array}{l}\text { Fighting against diseases may be } \\
\text { difficult }\end{array}$ & 1 & 2.1 \\
\hline Insufficient labor work and time & 8 & 16.7 \\
\hline Insufficient financial possibilities & 1 & 2.1 \\
\hline High costs & 1 & 2.1 \\
\hline Old age & 3 & 6.3 \\
\hline Total & 48 & 100.0 \\
\hline
\end{tabular}

*More than one answer was received 
Table 4. Factors that may be effective in farmers' tendency to produce organic milk in the future.

\begin{tabular}{|l|c|}
\hline & $\begin{array}{c}\text { Average Likert } \\
\text { score* }\end{array}$ \\
\hline Price & 4.56 \\
\hline Market guarantee & 4.09 \\
\hline Demand increase for organic milk & 3.87 \\
\hline Farmers' health & 3.71 \\
\hline Environmental consciousness & 3.62 \\
\hline Increase of subsidy for organic agriculture & 3.59 \\
\hline $\begin{array}{l}\text { Neighbors' and friends' tendency to organic } \\
\text { agriculture }\end{array}$ & 3.50 \\
\hline $\begin{array}{l}\text { Agricultural extension activities for organic } \\
\text { agriculture }\end{array}$ & 3.46 \\
\hline Decrease of expenses & 3.40 \\
\hline
\end{tabular}

*1 - not important; 5 - very important.

opinions about producing organic milk in the future were analyzed, it was determined that economic factors were primary. The most important factor was price. In other words, the farmers stated that they might produce organic milk provided that organic milk prices were higher than conventional milk prices. Market guarantee is the other effective factor on the farmers' tendencies to produce organic milk. So the farmers stated that they might produce organic milk in the case that they were sure that the milk produced would sell. In the study, the third factor that may be effective on the farmers' tendencies to produce organic milk was detected to be consumer demand for organic milk. In other words, the farmers stated that they might tend to produce organic milk if organic milk consumption increased (Table 4).

\section{Econometric Results}

The results of probit analysis conducted for the purpose of determining the factors that affect farmers' tendencies to produce organic milk are given in Table 5. The model was found to be significant for $\alpha<0.05$. (LR $\left.\chi^{2}(22)=68.61\right)$. The fit of the model would be considered to be adequate, since the $\chi^{2}$ value of 2.95 on eight degrees of freedom is not large $(\mathrm{p}=0.9376)$. So this model fits the data well.

According to the conducted probit analysis results, a positive relationship was found between considering enlarging the farm, applying innovations, being informed about organic agriculture, and farmers' tendencies to produce organic milk in the future. On the other hand, a negative relationship was determined between the distance of the farm to the Milas district center, educational level of the farmers, and farmers' tendencies to produce organic milk in the future. In other words, the farmers who consider enlarging their farms, applying innovations, and having information about organic agriculture are likely to produce organic milk. Besides, the farmers who have farms closer to the city center are likely to produce organic milk in the future. In the study, the possibilities to produce organic milk in the future of the farmers with lower educational levels were found to be higher. In fact, this is an unexpected result. However, in the literature there are many studies stating that there is no relationship or a negative relationship between the educational levels of the farmers and their adoption of innovations [41-44].

Marginal effects show the change in probability when the predictor or independent variable increases by one unit. For continuous variables this represents the instantaneous change given when the 'unit' may be very small. For binary variables, the change is from 0 to 1 (so one 'unit' as it is usually thought) [45]. We found that a one-unit $(1 \mathrm{~km})$ increase in the distance of farms to Milas district center decreased the tendency to produce organic milk in the future at a rate of $55.7 \%$. The farmers who apply agricultural innovations tend to produce organic milk in the future more than the farmers who do not apply at the rate of $56.1 \%$. The farmers who consider enlarging their farms tend to produce organic milk in the future more than the farmers who do not consider at the rate of $93.7 \%$.

Table 5. Probit regression model results.

\begin{tabular}{|c|c|c|}
\hline Acronym & Coefficient & Marginal effect \\
\hline AGE & $-0.3095725(1.379468)$ & $-0.1044531(0.42911)$ \\
\hline EDU & $-3.223867 * *(1.576727)$ & $-0.5547937 * * *(0.17842)$ \\
\hline HOUS & $-1.757012(1.667418)$ & $-0.6195465(0.43902)$ \\
\hline AGEX & $-0.5943067(1.89397)$ & $-0.2239813(0.7186)$ \\
\hline ANEX & $-0.641266(1.21331)$ & $-0.236649(0.45327)$ \\
\hline DIST & $-2.699913 *(1.588922)$ & $-0.5574547 * * *(0.18313)$ \\
\hline ANIM & $0.1828031(1.82242)$ & $0.066614(0.66983)$ \\
\hline MILK & $-4.293427(2.737561)$ & $-0.697558 * * *(0.24802)$ \\
\hline MILA & $0.0172593(1.164288)$ & $0.0062209(0.41917)$ \\
\hline CROP & $-1.059507(2.733805)$ & $-0.4037121(0.94528)$ \\
\hline NON & $-2.235812(1.447497)$ & $-0.6314459 * *(0.2534)$ \\
\hline CRED & $-0.6837628(1.094278)$ & $-0.2547127(0.40506)$ \\
\hline INCR & $3.722725 *(2.175537)$ & $0.9373047 * * *(0.15314)$ \\
\hline BEEF & $1.487761(1.195459)$ & $0.4660536(0.31933)$ \\
\hline REC & $-1.467533(1.236248)$ & $-0.4191488 *(0.24193)$ \\
\hline CONT & $1.534726(1.178806)$ & $0.4386824(0.2885)$ \\
\hline SILA & $-1.359166(1.498886)$ & $-0.5025209(0.4812)$ \\
\hline FORA & $0.6687725(1.899826)$ & $0.212091(0.493)$ \\
\hline COOP & $1.314219(1.103124)$ & $0.4585308(0.3319)$ \\
\hline INNO & $5.365313 *(2.75599)$ & $0.5614426 * * *(0.17423)$ \\
\hline ORGA & $3.563944 * * *(1.327854)$ & $0.8374782 * * *(0.14314)$ \\
\hline SEMI & $0.382139(0.9131037)$ & $0.1397829(0.33673)$ \\
\hline
\end{tabular}

*significant at $10 \%$; **significant at $5 \%$;*** significant at $1 \%$ Pseudo $\mathrm{R}^{2}=0.7020$ 


\section{Discussion and Conclusions}

Many factors may affect farmers' decisions to adopt organic agriculture. Among these factors are the economic conditions and personal characteristics of the farmers, agricultural production patterns, and farm size and agricultural policies of the state regarding organic agriculture.

Organic agriculture is an innovation for dairy farming in Milas District because there is no farmer engaged in organic milk production. Economic factors were determined to be the most effective factors for the farmers' tendencies to produce organic milk in the future. High prices, market guarantee, and increasing customer demands for organic milk are the most effective factors for the farmers to tend toward organic agriculture.

High price, market guarantee, and easy marketing conditions are important factors for adoption of organic farming by farmers [46]. The main reasons for farmers joining organic farming were the better prices of and the secure market for organic produce, environmental protection, and health problems due to the use of chemicals as well as agronomic problems in conventional farming [47]. Organic support payments emerge as an important driving factor of adoption over time [48]. Premium pricing and outside support (technical training, extension services, etc.) significantly contribute to decisions to switch to organic tea production [49]. Farmers will adopt organic land use management across a range of crop prices subject to farm location, farm size, and preference grouping [50]. The main motivations for future conversions are related to economic and farm-management reasons [51]. Economic factors are very important for adoption of organic farming by farmers [52]

It was determined that an important number of the participating farmers had information about organic agriculture. However, the main reason for farmers to tend not to produce organic milk in the future was not having sufficient information about organic agriculture. Therefore, courses and seminars should be held to increase the knowledge level of farmers in the district about organic stockbreeding. In addition, education and extension activities aimed at organic milk production should be organized. Education, innovation, self-confidence, information-seeking behavior, awareness, knowledge, and attitudes toward organic farming practices showed significant correlation with adoption [53]. Education can be good predictors of the intention of conventional farmers to convert to organic farming [20]. Extension/education was very important for adoption of organic farming by farmers [52]. University education and agricultural professional training both increase the probability of becoming an organic farmer [54].

According to the applied probit analysis a positive relationship was determined between considering enlarging the farm and farmers' tendencies to produce organic milk in the future. Farm size showed a significantly positive relationship with attitude to organic farming practices [55]. Farmers with larger farms are more likely to adopt organic production [56]. Having a more diversified production structure has a positive impact on the intention for being organic farmers [57].
It can be said that the Milas farmers in are open to agricultural innovations because $88.7 \%$ of the interviewed farmers stated that they applied agricultural innovations. Only $11.3 \%$ of the farmers said that they did not apply agricultural innovations. On the other hand, according to the applied probit analysis, a positive relationship was detected between applying innovations and tendencies to produce organic milk in the future. This can be evaluated as a positive circumstance with regards to the possibility of adopting organic agriculture in milk production in the district.

Although organic agriculture has not yet started in animal production, organic agriculture has been undertaken in plant production in the district. This can be evaluated as a positive circumstance with regards to the engagement and development in organic dairy farming in the district. Farmers who have recently undertaken the management of the farm, who embrace risk, and who are willing to preserve the environment and generate employment in their area are more prone to adopt organic farming in a shorter period of time [58].

An important number of the farmers did not consider engaging in organic agriculture in the future since organic milk is not being produced around them. This result is important with regards to ensuring that the farmers adopt organic agriculture. In other words, the farmers stated that they might start organic agriculture if their friends did likewise. Farmers who act in accordance with their neighbors' expectations and with greater availability of information in their neighborhood network are more likely to adopt organic agriculture [59].

Some farmers do not want to convert to organic agriculture because they think that fighting against disease is not easy. Some farmers also think that organic agriculture requires more effort than conventional agriculture. These opinions show that the farmers do not have sufficient information about organic agriculture. Therefore, agricultural education and extension activities are seen as extremely important for farmers in the district to receive the correct information and to adopt and apply organic agriculture and organic milk production. Farmers' motivation and perceptions about organic farming, social attitudes, ecological attitudes, and participation in extension activities are the main determinants of adoption of organic farming among small farmers [60]. Farmers' participation in organic farmingrelated training and visits, farm size, and compatibility of organic farming to their situations are the main determinants of adoption of organic farming [61].

The survey was conducted with 71 farmers in this study. Surveys were conducted by the researcher personally. The surveys were conducted in village coffeehouses and participants' farms. This article was written to determine whether the dairy farmers were sufficiently informed about organic agriculture, their tendencies to produce organic milk, and the factors that affect their tendencies to produce organic milk. The farmers that consider enlarging their farms tend to engage in organic agriculture. Therefore, farmers should be supported in enlarging their farms, rural development projects should be applied, and loan facilities with low interest rates should be offered to the farmers. Another 
result obtained from probit analysis is that the farmers who have information about organic agriculture are more likely to produce organic milk in the future than farmers who do not have information about organic agriculture. Therefore, agricultural extension institutions should prepare programs about organic agriculture, so the knowledge level about organic agriculture of farmers could be improved.

\section{Acknowledgements}

I wish to thank all farmers that participated in my study.

\section{References}

1. The principles of organic agriculture, available in: http://infohub.ifoam.org/en/what-organic/principles-organic-agriculture, 2015.

2. ALTINDISŞLİ A., AKSOY U. Situation of organic agriculture in the world and in Turkey, Turkey Agricultural Engineering $7^{\text {th }}$ Technical Congress, 2010 [In Turkish].

3. TÜİK (Turkish Statistical Institute). Turkey in Statisticts 2013, Ankara, Turkey, 2014.

4. SANER G., ENGINDENIZ S. An evaluation on production and market opportunities of organic animal products in Turkey. Journal of World-Food, 8, 78, 2005 [In Turkish].

5. Çİ̧EK T., TANDOĞAN M. A Review in point of production costs and profitability in organic dairy. Kafkas Univ Vet Fak Derg., 15, (1), 145, 2009 [In Turkish].

6. BUTLER L.J. Survey quantifies cost of organic milk production in California. California Agriculture, 56, (5), 157, 2002.

7. DALTON T.J., PARSONS R., KERSBERGEN R., ROGERS G., KAUPPILA D., MCCRORY L., BRAGG L.A., WANG Q.A. Comparative Analysis of Organic Dairy Farms in Maine and Vermont: Farm Financial Information from 2004-2006, Bulletin 851, University of Maine, Maine Agricultural and Forest Experiment Station, 2008.

8. TRANEL L. The Economics of Organic Dairying, Iowa State University Extension and Outreach, 2014.

9. BENNETT M., FRANZEL S. Can organic and resourceconserving agriculture improve livelihoods? A synthesis. International Journal of Agricultural Sustainability, 11, 3, 193, 2013.

10. MCBRIDE W.D., GRENE C.R. A Comparison of Conventional and Organic Milk Production Systems in the U.S. Proceedings of the American Agricultural Economics Association Annual Meeting, Portland, Oregon, 2007.

11. PARSONS B. Vermont's Dairy Sector: Is there a Sustainable Future for the $800 \mathrm{Lb}$. Gorilla?. Food System Research Collaborative at the University of Vermont Center for Rural Studies Opportunities for Agriculture Working Paper Series, 1, (4), 12, 2010.

12. NEMES N. Comparative analysis of organic and non-organic farming systems: a critical assessment of farm profitability. Food and Agriculture Organization of the United Nations Natural Resources Management Environment Department, pp. 33, 2009.

13. KARABAŞ S., GÜRLER A.Z. A Comparative Analysis of Organic Farm and Conventional Farm. Journal of Social and Economic Research of Karamanoglu Mehmetbey University, 13, (21), 75, 2011 [In Turkish].
14. BAYRAM B., YANAR M., AKBULUT Ö. Reproductive and milk production traits of holstein friesian cows in preorganic and organic dairy husdandry in Turkey. Journal of Animal and Veterinary Advances, 7, (7), 808, 2008.

15. KIZILASLAN H., OLGUN A. Organic agriculture and supports given to organic agriculture in Turkey. Journal of Agricultural Faculty of Gaziosmanpasa University, 29, (1), 1, 2012 [In Turkish].

16. KOYUBENBE N., KONCA Y. Organic meat production and prices in the EU and Turkey. Proceedings of the $10^{\text {th }}$ National Agricultural Congress, pp. 985-995, Konya, Turkey, 2012 [In Turkish].

17. DEMIRYÜREK K. The concept of organic agriculture and current status of in the world and Turkey. Journal of Agricultural Faculty of Gaziosmanpasa University, 28, (1), 27, 2011 [In Turkish].

18. Announcement for Organic Stockbreeding Support Payment. Published on 20.07.2013 No. 28713, Official Newspapes of Turkish Republic, 2013.

19. Milas Directorate of District Food Agriculture and Livestock Records, 2014.

20. SHABAN A.A. Factors influencing farmers' decision to shift to organic farming: The case of Gaza Strip. British Journal of Economics, Management \& Trade, 5, (1), 78, 2015.

21. ACS S., BERENTSEN P.B.M., HUIRNE R.B.M. Conversion to organic arable farming in The Netherlands: A dynamic linear programming analysis. Agr. Syst., 94, 405, 2007.

22. DE COCK L. Determinants of organic farming conversion. Proceedings of the $\mathrm{XI}^{\text {th }}$ EAAE Congress, The Future of Rural Europe in the Global Agri-Food System, Copenhagen, Denmark, 2005.

23. KALLAS Z., SERRA T., GIL J.M. Farmer's objectives as determinant factors of organic farming adoption. Proceedings of the $113^{\text {th }}$ EAAE Seminar A Resilient European Food Industry and Food Chain in a Challenging World, Chania, Crete, Greece, 2009.

24. MZOUGHI N. Farmers adoption of integrated crop protection and organic farming: do moral and social concerns matter?. Ecol. Econ. 70, 1536, 2011.

25. CONSTANCE D.H., CHOI J.Y. Overcoming the barriers to organic adoption in the United States: A look at pragmatic conventional producers in Texas. Sustainability, 2, 163, 2010.

26. SINGH M., MAHARJAN K.L., MASKEY B. Factors impacting adoption of organic farming in Chitwan district of Nepal. Asian Journal of Agriculture and Rural Development, 5, (1), $1,2015$.

27. KHALEDI M., WESEEN S., SAWYER E., FERGUSON S., RICHARD G. Factors influencing partial and complete adoption of organic farming practices in Saskatchewan, Canada. Can. J. Agr. Econ., 58, (1), 37, 2010.

28. NAHUELHUAL L., ENGLER M.A., CARRILlO B., MOREIRA V., CASTRO I. Adoption of cleaner production practices by dairy farmers in southern Chile. Cien. Inv. Agr. 36, (1), 97, 2009

29. LATRUFFE L., NAUGES C., DESJEUX Y. Technical efficiency and technology adoption: a study of organic farming in the French dairy sector. Proceedings of the $12^{\text {th }}$ International Conference on Data Envelopment Analysis, Kuala Lumpur, Malaysia, 2014.

30. LATRUFFE L., NAUGES C., DESJEUX Y. Drivers inducing and preventing conversion to organic farming for dairy and vegetable farmers: findings of a large-scale survey in the 
French regions of Brittany and Pays de la Loire. Deliverable 2 - Research Project "Role of Farm and Sector Economic Performance and Public Policies in the Development of Organic Farming in France," 2013.

31. ASADOLLAHPOUR A., NAJAFABADI M.O., HOSSEINI S.J. Factors affecting the conversion to organic farming in Iran: a case study of Mazandaran rice producers. Sci. Int. (Lahore), 26, (4), 1665, 2014.

32. AZAM M.S. The influence of socio-demographic factors in adopting organic farming practices. International Journal of Interdisciplinary and Multidisciplinary Studies, 2, (5), 8, 2015.

33. SHARIFI O., SADATI S.A., GHOBADI F.R., SADATI S.A., MOHAMAD Y., DEL P.T.T. Barriers to conversion to organic farming: A case study in Babol County in Iran. African Journal of Agricultural Research, 5, (16), 2260, 2010.

34. PADEL S. Conversion to organic farming: A typical example of the diffusion of an innovation?. Sociol. Ruralis, 41, (1), 41, 2001.

35. SARKER M.A., ITOHARA Y., HOQUE M. Determinants of adoption decisions: The case of organic farming (OF) in Bangladesh. Extension Farming Systems Journal, 5, (2), 39, 2009.

36. ISIN F., CUKUR T., ARMAGAN G. Factors affecting the adoption of the organic dried fig agriculture system in Turkey. Journal of Applied Sciences 7, (5), 748, 2007.

37. NEWBOLD P. Statistics for Business and Economics. Prentice-Hall International, New Jersey, pp. 867, 1995.

38. GUJARATI D.N. Basic Econometrics. The McGraw-Hill Companies Fourth Edition, pp. 1002, 2004.

39. MAROTTA D., MARK M., BLOM A., THORN K. Human Capital and University-Industry Linkages' Role in Fostering Firm Innovation: An Emprical Study of Chile and Colombia, The World Bank Latin American and the Caribbean Region Human Development Sector Unit, Policy Research Working Paper 4443, 2007.

40. ÖZEN N., ŞAYAN Y., AK İ., YURTMAN İ.Y., POLAT M. Animal production-environment relations and organic livestock, Turkey Agricultural Engineering $7^{\text {th }}$ Technical Congress, 2010 [In Turkish].

41. DIEDEREN P., VAN MEJIL H., WOLTERS A. Modernisation in agriculture: what makes a farmer adopt an innovation?. Int. J. Agricultural Resources, Governance and Ecology 2, (3/4), 328, 2003.

42. FABIYI E.F., HAMIDU B.M. Adoption of improved technologies in soyabean processing and utilization in tafawa balewa local government area of bauchi state, Nigeria, African Journal of Food, Agriculture, Nutrition and Development 11, (1), 4527, 2011.

43. ANNOR S.Y., KUSI C. Factors influencing the adoption of grasscutter production in the Brong Ahafo region of Ghana, Livestock Research for Rural Development 20, (9), available in: http://www.lrrd.org//rrd20/9/anno20141.html, 2008.

44. LENCSES E., TAKACS I., TAKACS-GYÖRGY K. Farmers' perception of precision farming technology among Hungarian farmers, Sustainability 6, 8452, 2014.

45. REYNA O.T. Predicted probabilities and marginal effects after (ordered) logit/probit using margins in Stata, available in: http://www.princeton.edu/ otorres/Margins.pdf, 2014.

46. OLGUN A., ARTUKOĞLU M.M., ADANACIOĞLU H. Research on the tendencies of conventional olive producers to convert to organic olive production, The Journal of Agricultural Faculty Ege University. 45, (2), 95, 2008 [In Turkish].

47. ALEXOPOULOS G., KOUTSOURIS A., TZOURAMANI I. Should I stay or should I go? Factors affecting farmers' decision to convert to organic farming as well as to abandon it, 9th European IFSA Symposium, Vienna, Austria, 2010.

48. LAPPLE D., DONNELLAN T. Adoption and abandonment of organic farming an empirical investigation of the Irish drystock sector, The $83^{\text {rd }}$ Annual Conference of the Agricultural Economics Society, Dublin, 2009.

49. TRAN N.D. Transition to Organic Tea Production in Thai Nguyen Province, Vietnam: Economic and Environmental Impacts. Economy and Environment Program for Southeast Asia Research Report No. 2008-RR8, Singapore, 2008.

50. HOPE R.A., BORGOYARY M., AGARWAL C. Incentives that work for farmers and wetlands - a case study from the Bhoj wetland, India, Project technical report for DFID FRP R8174: Socio-economic opportunities from upland catchment environmental services: A Negotiation Support System, 2006.

51. KAUFMANN P., ZEMECKIS R., SKULSKIS V., KAIRYTE E., STAGL S. The diffusion of organic farming in Lithuania. J. Sustain. Agr., 35, (5), 522, 2011.

52. HOSSEINI S.J., AJOUDANI Z. Affective factors in adopting organic farming in Iran. Annals of Biological Research, 3, (1), 601, 2012.

53. JAYAWARDANA J.K.J.P., SHERIEF A.K. Influence of socio-psychological characteristics in adoption of organic farming practices in coconut based homesteads in humid tropics, COCOS 19, 101-104, 2010.

54. BELTRAN-ESTEVE M., PICAZO-TADEO A.J., REIGMARTINEZ E. What makes a citrus farmer go 'organic'? Empirical evidence from Spanish citrus farming. Spanish Journal of Agricultural Research 10, (4), 901, 2012.

55. ADEBAYO S.A., OLADELE O.I. Vegetable farmers' attitude towards organic agriculture practices in South Western Nigeria. Journal of Food, Agriculture \& Environment 11, (2), 548, 2013.

56. KARKI L., SCHLEENBECKER R., HAMM U. Factors influencing a conversion to organic farming in Nepalese tea farms, Journal of Agriculture and Rural Development in the Tropics and Subtropics 112, (2), 113, 2011.

57. FERTÖ I., FORGACS C. Is organic farming a chance for family farms to survive?, 111 EAAE-IAAE Seminar Small Farms: decline or persistence, 26-27 $7^{\text {th }}$ June 2009, University of Kent, Canterbury, UK, 2009.

58. KALLAS Z., SERRA T., GIL J.M. Farmer's objectives as determinant factors of organic farming adoption, $113^{\text {th }}$ EAAE Seminar A resilient European food industry and food chain in a challenging world, Chania, Crete, Greece, 2009.

59. WOLLNI M., ANDERSSON C. Spatial patterns of organic agriculture adoption: evidence from Honduras, Selected Paper prepared for presentation at the AEL (Research Committee on Development Economics) Conference, Munich, 2013.

60. REZVANFAR A., ERAKTAN G., OLHAN E. Determine of factors associated with the adoption of organic agriculture among small farmers in Iran. African Journal of Agricultural Research 6, (13), 2950, 2011.

61. KAFLE B. Factors affecting adoption of organic vegetable farming in Chitwan District, Nepal. World Journal of Agricultural Sciences 7, (5), 604, 2011. 
